\title{
РЕАЛЬНІСТЬ МІФУ: СТРУКТУРНО-ГЕРМЕНЕВТИЧНИЙ АНАЛІЗ
}

\section{Г.А. Балута}

Важливим джерелом давнього мислення був міф, який не втратив своєї «таємної» влади над ratio протягом тисячоліть. Укоріненість міфу в людській свідомості надзвичайна, раз у раз ми повертаємося до міфів в пошуках відповідей на життєві питання або ж поринаємо в них як джерела, що мають високу інформативність у галузі культурної антропології, епістемології, психології, соціальної філософiї та ін. Існує думка, що у ХХ ст. відбувається зміщення акцентів 3 класичної філософії суб'єкта в бік проблеми індивідуального суб'єкта як такого, що конституює смисл. Зокрема, М. Фуко зазначає: «Стало неможливо уникати двох заздалегідь прихованих теоретичних парадоксів. Перший полягав у тому, що філософія свідомості не змогла побудувати філософію знання, в особливості-наукового, а другий в тому, що парадоксальним чином подібна філософія смислу не врахувала формуючі механізми сигніфікації і структуру знакових систем» [8, с. 69]. Зрештою вимальовується дві філософські перспективи, які можна розглядати як шляхи подолання «філософії суб'єкта»: теорія об'єктивного знання, що розроблялася в руслі позитивізму, та дослідження знакових систем, на якому сконцентрували свою увагу окремі школи філософської антропології, психоаналізу, неокантіанства, структуралізму. Важливе місце серед таких систем посідає міф та символ. «Аналіз будь-якої символічної форми ставить нас у залежність від історичних даних. На питання: що є міф, релігія, мистецтво, мова? не можна дати відповідь, спираючись на абстракції і логічні дефініції. 3 іншого боку, при вивченні релігії, мистецтва і мови ми завжди стикаємося із загальними структурними проблемами, які відносяться до

Актуальні проблеми духовності:

зб. наук. праць / Ред.: Я.В. Шрамко

Вип. 10. - Кривий Ріг, 2009, 30-40 
різних видів пізнання», - так актуалізує проблему Е. Кассірер [2, с. 11]. Чи існує строга демаркація між поняттями «слово», «символ», «міф» як реальностями базисного порядку і водночас інваріантами індивідуального смислу? Тут можна визначити декілька важливих проблем: з'ясування логіки та функцій міфу, принципів його впорядкування, особливостей символічної мови.

Вже у філософії Піфагора, Геракліта і Платона відчувається, що міф не можна віднести ні до релігії, ні до філософії і в той же час його можна розглядати як синкретичну релігійно-філософську модель реальності. Не буде зайвим нагадати також і думку дослідників, зокрема Е. Берна, про те, що міф лягає в основу «життєвого проекту» як організуючий принцип психічної реальності. Таким чином, міф виступає дискурсом, що поєднує суб'єктивне та об'єктивне; системою мислення, що репрезентує специфічну парадигму з притаманними їй поняттєвими та логічними особливостями.

На думку А.С. Майданова, життєвий досвід архаїчної людини виступав як єдиний концептуальний апарат формування понять. Таким чином, нові явища та об'єкти, що виходили за межі наявної концептуальної системи набували специфічного змісту, що був підпорядкований міфологічному мисленню (див. [5]). А.С. Майданов вважає, що у процесі розвитку виник специфічний понятійний апарат, який репрезентує реальність у іншій формі. Таким чином, міф як комбінація реального і вигаданого розглядається ним як не пряма, а викривлена демонстрація об'єктивного стану речей. Так утворювалися міфеми складні концептуальні одиниці, що поєднували реальне і надреальне. Надалі міфеми як поняття використовувалися для позначення нових явищ, набуваючи семантичних нашарувань, що в результаті значно ускладнило герменевтичний аналіз міфу (див. [5, с. 100-101]).

Генеалогія міфу тісно пов'язана з творчістю Гомера, який подав міфи у вигляді іонійського героїко-філософського епосу «Іліади» i «Одісеї»-безцінних і неперевершених шедеврів світової культури. Етимологія самого поняття міфу пов'язана зі «словом», «історією», «розповіддю». Згідно з поглядами Е. Кассірера (див. [2]) саме етимологія як висвітлення значення першого порядку відіграє вирішальне значення у аналізі зв'язку міф-символ-мова-людина-світ. Дійсно, давньоєгипетські, давньогрецькі міфи та біблійні перекази демонструють надзвичайно цінні космогонічні, антропологічні, етико-естетичні уявлення, пов'язані з етимологією базисних понять, постійно відкритих для філософської та художньої інтерпретації. Варто звернути увагу на те, скільки «міфологічного» ми знаходимо в поглядах Піфагора, Гераклі- 
та, Платона, Й.Шеллінга, А.Шопенгауера, Ф. Ніцше, З.Фрейда, К.Г. Юнга, О. Лосєва, М. Фуко, К. Леві-Строса, Ж. Лакана, К. Хюбнера, Е. Кассірера та ін. Зокрема міфологічний символізм лягає в основу не тільки гераклітівських чи платонових філософських метафоризацій, а виступає фундаментом понятійного психоаналітичного апарату, зокрема в поглядах 3. Фрейда (Едіпів комплекс, Ерос і Танатос) та К.Г. Юнга (колективні архетипи). Всі вони розглядають міф як важливий життєвий грунт, від якого все більш віддаляється сучасна людина.

Наприклад, З. Фрейд розглядав міф як символічну проекцію психічних законів. Зокрема він обережно констатує, що однозначність у питанні співставлення змісту міфів з фундаментальними законами людської природи є можливою тільки у випадку попереднього з'ясування справжньої природи міфів [6, с. 199]; К.-Г. Юнг вважає міфологію вираженням універсально-людського колективного несвідомого. Він репрезентує міфологічне мислення як надзвичайно важливий вимір людського буття. Синкретизм міфу є своєрідною формою адаптації як до зовнішнього, так і до внутрішнього, за допомогою репрезентованих ним спадкових поведінкових і мотиваційних детермінант. Отже, міф $є$ не тільки світоглядною системою чи джерелом особистого знання, а й певним принципом організації життєвого досвіду.

Сучасний етап аналізу міфу піднімає ряд проблем, зокрема проблему розуміння, і продовжує загальну традицію пошуку реальних референтів (об'єктів, закономірностей, явищ) та міфологічних інваріантів, представлених езотеричним змістом. В своєму дослідженні ми ставили за мету: розглянути деякі прийоми і методи аналізу міфу, виявити його структурні особливості, проаналізувати специфіку міфу у співвідношенні з його логікою. В ході аналізу ми взяли до уваги напрям дослідження, започаткований А.С. Майдановим впродовж дослідження ним індоарійських міфів, що традиційно вважаються найбільш складними для прочитання [5, с.91-106]. Взагалі специфіка міфу привертала увагу багатьох дослідників, зокрема, В.Я.Проппа, Я.В. Чеснова, М. Еліаде, Ф.Б.Я. Кейпера, Б.І. Вронського та ін. Теоретично-філософська систематизація основних підходів до з'ясування та обгрунтування природи і феномену міфу викладена у відомій праці К. Хюбнера «Істина міфу» [9]. У ній автор виокремлює алегоричну та евгемеричну традиції інтерпретації міфу, розглядає міф як «хворобу мови» в контексті ідей М. Мюллера (власне роботу Е. Кассірера [2] можна експлікувати як його критичну реакцію на ідеї, запропоновані М. Мюллером); аналізує міф як ритуально-соціологічну модель (Дж. Фрезер, Е. Дюркгейм), подає розуміння міфу в межах психоаналітичного підходу (З. Фрейд, 
К.-Г. Юнг), висвітлює символічну, трансцендентальну (Е. Кассірер) та структуралістську (К. Леві-Строс) версії міфу ${ }^{1}$. Так, символічна інтерпретація розглядає взаємозв'язок міфу та символу як єдності знання та мислення. Міф «розповідає», символ «фіксує» смисл розказаного (повторюваного $)^{2}$. Крім цього існують й інші теорії міфу. Наприклад, Дж. Хаббекк виокремлює натуралістичну, етіологічну, інституційну, генетичну, ритуальну, «дієву» теорії [11, с. 266-271].

Е. Кассірер констатує, що у міфі закладено передумови пізнання та досвіду, тобто обгрунтовує наявність системи чуттєвих і поняттєвих форм, що забезпечують конституювання смислу, виходячи з констатації функціональної єдності мови та міфу. Як мова, так і міф грунтуються на ранньому досвіді людства, що має соціальну природу $[2$, c.4]. Зокрема він зазначає: «Не матеріальний, а людський світ-ось ключ до вірного прояснення космічного порядку» $[2$, с. 5]. В свою чергу K. Леві-Строс розглядає міф як історично організовану форму досвіду, форму знання про логічні відношення предметів між собою ${ }^{3}$ К. ЛевіСтрос аналізує міф як стійкий інваріант культури, специфічну модель з власною системою структурних одиниць, що лягає в основу несвідомого, причому «термін несвідоме позначає символічну функцію» $[3$, c.180]. Інакше кажучи, філософ досліджує міф як структуру колективного досвіду, наближаючись до юнгіанського тлумачення міфу, на відміну від поглядів З. Фрейда.

Відмітимо, що для логічного мислення характерною $є$ екстравертність, спрямованість на зовнішню реальність - знання в такому випадку можна мислити як «інтенцію», «орієнтовану» як функція «зовнішньої адаптації». Міфологічне мислення $\epsilon$ інтроспективно-образною грою уяви, яка вибудовується за іншими законами у відповідності з іншими сенсами. Міфологічне світопереживання як архаїчна форма світосприйняття чи «глибинна» психічна структура виявляється більш природною у екзистенціальному вимірі та непродуктивним, як на перший погляд, пристосуванням до зовнішньої реальності, проте вкрай необхідним для реалізації творчості, внутрішнього психологічного балансу, гармонізації зовнішнього і внутрішнього, що у свою чергу лягає

\footnotetext{
${ }^{1}$ На наш погляд, слід зазначати, що дана систематизація є досить умовною, оскільки вона не володіє ясно визначеними диференціальними критеріями.

${ }^{2}$ Наприклад, темою символізму пронизана семантична мовно-філософська парадигма - Платон, М. Кузанський, О.Лосєв.

${ }^{3} \mathrm{~B}$ такому випадку «логіка» міфу розглядається як певний інструмент чи закон, що дозволяє фіксувати цілісність та системність міфологічної реальності, внутрішній взаємозв'язок всіх його елементів, виходячи зі специфічної когнітивної моделі.
} 
в основу конституювання індивідуального «Я». На відміну від Фрейда, який побачив у міфах зміст психологічних феноменів, К.-Г.Юнг розглянув міф у набагато ширшому соціокультурному контексті на матеріалі вчення про колективні архетипи.

Колективне несвідоме складають праформи, які знаходять відображення в міфах - така головна ідея Юнга знаходить обгрунтування у низці його відомих праць, серед яких найбільш показовою у цьому відношенні $\epsilon$ «Архетип і символ». «Навіть якщо б всі релігійно-міфологічні традиції були одним ударом знищенні, - констатує А. Руткевич, дослідник життєвого шляху і філософської спадку К.-Г. Юнга, - то вся міфологія відродилася б вже в наступному поколінні, оскільки символи релігії та міфології укорінені в психіці кожного індивіда, вони успадковані нами від тисяч поколінь» [11, с.22]. Всі людські спроби зруйнувати міф і знайти щось нове у кінцевому підсумку наштовхуються на те, що «нове»- це забуте старе, навантажене смислами та цінностями тієї чи іншої історичної доби. Яскравим прикладом є психоаналітичні концепти, пов'язані з неперевершеними за своєю філософською програмою образами. На нашу думку, внутрішня сторона міфу $\epsilon$ структурно впорядкованою, зовнішня - $\epsilon$ синкретичною цілісністю, явним сюжетом, що забезпечує міфу формальний (сюжетний або ж поверховий) характер ніби-то відкритого, проте, насправді, «закритого» знання. Наприклад, відмежування свідомого і несвідомого, що описується в міфах, витлумачується як гріхопадіння і водночас своєрідна піднесеність людського духу, що не дозволяє однозначно зрозуміти подібну логіку, яка сягає глибин культурогенеза, якщо виходити з версій розуміння людини як «символічної істоти».

Мова символів є мовою, за допомогою якої внутрішній зміст набуває зовнішніх об'єктивацій і має специфічну логіку, відмінну від логіки інструментальної мови. «Логіка, в якій головними категоріями є не час і простір, а інтенсивність і асоціативність. Це єдина універсальна мова, відкрита людством, єдина для всіх культур у всій історії. Це мова з власною граматикою і синтаксисом, яку треба розуміти, якщо хочеш зрозуміти смисл міфів, казок і снів»,- відзначає Е. Фромм [7, с. 328]. Згідно з його думкою, фундаментальний зв'язок людини і свободи вже показаний в біблійному міфі про гріхопадіння Адама і Єви: «Міф ототожнює початок людської історії з актом вибору, але при цьому особливо підкреслює гріховність першого акту свободи і ті страждання, які явились його наслідком... Згідно з міфом, формально гріх полягав у тому, що людина вкусила від дерева пізнання. Таким чином, акт непокори, акт свободи прямо пов'язується з початком людського ми- 
слення. Міф говорить про інші наслідки цього першого акту свободи» [7, с. 297]. Отже, під літературною фабулою приховано інший вид знання, відмінний від поверхової інформації, що прочитується лише на даний момент часу. Ми розглядаємо його як статичну інформаційну реальність, інваріант, що варіюється у різних культурних стратегіях та формах.

3 цього приводу окремо згадаємо «структурну психологію» Е. Берна, згідно з яким життя - це безперервне розгортання життєвого плану співвіднесеного зі сценарієм - найбільш загальною, стандартизованою схемою життєвого плану [1, с. 37]. Дана точка зору доводить, що театральні сценарії походять 3 «життєвих», власне, обидва вони будуються на обмеженому наборі сюжетів. «Найвідомішим з них є трагедія Едіпа та ій подібні. Більшість інших сценаріїв також можна знайти серед грецької міфології...Тепер нам зрозуміло, що життя людини подібне античним драмам, в яких боги розмовляють з людьми і де проливаються сльози вселенського горя» [1, с.41]. У роботі «Люди, які грають в ігри» дослідник проводить аналогії між міфами, казками та життєвими сценаріями і звертається до попереднього досвіду Дж. Кемпбелла, К.-Г. Юнга, З. Фрейда.

О.Ранк, Е.Еріксон, А.Адлер поділяють думку про те, що міфічні сюжети та історії варті дослідницької уваги, оскільки в матеріалах досліджень життєвих ситуацій великої кількості людей в більшості випадків має місце повторюваність сюжетів та колізій, ніби життєвий план залишається у несвідомому. Звідси виникає проблемне питання про роль самої людини у її «життєвій драмі». Отже, міф можна розглядати як неусвідомлену життєву модель чи, навпаки, життєвий сенс, що конфігурує систему очікувань. В даному разі йдеться про дію міфу, на фоні якої виникають відомі у психології ефекти (наприклад, ефект Пігмаліона).

Міфологічні структури об'єктивовані у вигляді розмаїтого символічного контексту, що поєднує минуле і майбутнє, передчуття та реальність, раціональне та ірраціональне, проектуючись у найбільш видатних художніх і філософських творах. Архаїчне чуттєво-образне сприйняття поєднало у міфі різні, в тому числі й малодосліджені елементи реальності. Таким чином, міф не тільки можна розглядати як важливу інформацію, що стоїть за його образами і символами, а й повідомлення, що мінімізує ситуацію невизначеності, дозволяє здійснити оптимальний вибір, тобто конституює дію та, вірогідно, може також мати упереджений «формуючий» вплив. Зауважимо, що інтерпретацію міфу можна розглядати як текст, що його конституює суб'єкт. 
Основою міфу є символ-знак, який не просто вказує на відтворюваний об'єкт, а й виражає його смисл, фіксуючи його як цілісну структуру, що виходить за межі його очевидного і безпосереднього значення. Запозичене з грецької мови, це поняття означає «співпадання», «поєднання в одне ціле». Згідно з поглядами О.Ф. Лосєва, «символічна сфера пов'язана зі з'явою того, що онтологічно визнано абсолютно трансцендентним і неявним» [4, с. 74]. У поглядах А. Шопенгауера символ інтерпретується як центр, з якого відходить нескінченна кількість радіусів, образ, який кожний бачить згідно зі своєю точкою зору [10, с. 218]. Отже, унікальність символу полягає в тому, що поруч з відмінними суб'єктивними змістами ми мислимо і дещо для всіх спільне. Символ репрезентується смислом, який забезпечує внутрішній зв'язок символічних значень. Смисл задає спосіб розуміння єдності явищ зовнішнього і внутрішнього світу. Засобом смислової реконструкції чи правилом прочитання інформації є культурний код - механізм смислової реконструкції або правила розуміння інформації. На наш погляд, поняття культурного коду можна перш за все співвіднести з етнічною мовою як семантично-логічною базовою системою правил, що забезпечують процедури розуміння та мислення. Всі культурні повідомлення можна розглядати виходячи із спільного коду культурної ієрархії, однак деякі символи та смисли окремо взятої культури довгий час можуть залишатися закритими, оскільки мають відносно автономний культурний код.

Сучасне розуміння культури, що постулює їі як «символічну гру» з базовою системою правил, структурно впорядковану динамічну систему, опосередковану міфом (символом) не виходить за межі раціонального дискурсу. В ході дослідження ми надійшли висновку, який, здається, зустрічали в літературі, що міф можна інтерпретувати як розгорнутий символ, тобто розповідь, і навпаки, розглядати символ як «згорнутий» міф. При цьому важливо враховувати, що між абстрактними символами та символами-образами є змістові, семантичні та семіотичні відмінності, що полягають, у моносемії перших та полісемії других: об'єктивність абстрактного символу доповнюється (або протистоїть) суб'єктивним змістам символу-образу. (Така точка зору варіюється в концепціях мовного генезу, тобто безпосереднього зв'язку міфу і мови у процессі її становлення.)

Так, в давній Греції вважалося, що символ (знак) передає мову богів. В межах того чи іншого культурного коду у символіці проявляється інформація про універсальні закони зв'язку людина-світ. Греки вважали, що мова богів $є$ найбільш прозорою, однак людині вона не 
дається у вигляді прямого повідомлення, але людина не помічає чи спотворює їі, так виникає «загадка», яку треба дешифрувати. Вважалося, що звістку від богів витлумачує людям сам Гермес, син Зевса, посередник між богами і людьми. (Звідси виникла назва герменевтики - теорії розуміння та інтерпретації.) Герменевтичні процедури, що мали значне розповсюдження в історії та культурі давніх цивілізацій, як це описано, наприклад, у Плутарха, відігравали майже доленосну роль, у якій сама людина виявлялася «іграшкою»в руках богів; символ, проявлений у сновидінні, необхідно реалізував систему очікувань. Як повідомляє М. Фуко, тлумачення сновидінь розглядалось як «техніка випробовування себе». Якщо стоїки сприймали тлумачення сновидінь скептично, то Піфагор, Артемідор, Сінесій Кіренський, Елій Аристід вказували на важливість тлумачення сновидінь в повсякденному житті як одну з технік самопізнання чи конституювання себе [8, с. 114-115]. 3 огляду на це, можна припустити, що процедури витлумачення і подальшого розгортання подій грунтувалися на дії механізмів, специфіка яких остаточно невизначена. Такі процедури призводили до феноменологічних трансформацій, що на мові сучасної психології можна визначити як зміни стану свідомості суб'єкта і відповідну до цього заміну життєвого сценарію як ситуацію «втрати», чи навпаки, «збереження», відновлення.

Важливим елементом міфу є міфема - змістова одиниця, що виступає як образ чи концепт (див. [5, с. 104]). Однак здійснювати процедуру співвіднесення всієї міфеми з реальним прототипом треба з врахуванням того, що головна частина подана у непрямому, а опосередкованому вигляді. Так, в образі на перший план проступає та частина, яка є вторинною по відношенню до презентованого нею прототипу. Наприклад, «ранкова зірка» може виступати в образі юної дівчини, «справедливість» в образі богині тощо. Крім цього, в ході герменевтичних процедур можуть відкриватися нові смисли міфологічного концепту. Може мати місце полісемія міфем, тобто під однаковими образами можуть виступати різні прототипи. Логіка міфу полягає в тому, що сюжет міфу будується на основі явної (вторинної) частини, внаслідок чого міф набуває алегоричної форми. Така логіка схожа на логіку сновидіння, у якому спостерігається ніби згущення реальності чи, наприклад, проявлення інваріантних культурних структур - архетипів, що мають важливе змістове наповнення. В цій частині відмітимо, що міф має парадоксальну (антиномічну) природу, що знову таки споріднює його з логікою сновидінь.

Скористувавшись категоріально-методологічним базисом психоа- 
налізу у процедурах тлумачення сновидінь відмітимо, що текст міфу може будуватися як наслідок проективних механізмів, зокрема зміщення або ж конденсації. Згущення фіксує інтеграцію різних структур реальності у єдиному тексті. Так, під згущенням (конденсацією) Фрейд розуміє що лаконічний за змістом фрагмент може мати широкий обсяг, відкритий для прочитання i, навпаки, широкий зміст може не мати ніякого смислу. Єгипетська езотерична традиція фіксує антиномічність, що проявляється в оберненому змісті між реальністю та змістом сновидіння. Таке протистояння проявляється у міфі через бінарність «щастя-нешастя», «занепад-відродження» та інш.

В процесі згущення деякі смислові фрагменти, що забезпечують логічну змістову єдність, вилучаються, проте реалізуються як чудернацька гра слів, образів, ситуацій, тобто відбувається заміщення. Під заміщенням Фрейд розуміє процес, при якому прихований елемент заміщується на інший: другорядний елемент ніби відтіняє головний. Таким чином, у міфі як і в сновидінні спостерігається химерна гра натяків, іронії, алюзій, що відсилають до попереднього особистого чи загального соціокультурного досвіду.

Міф можна розглядати як феноменологічну структуру, яка вибудувана за своїми правилами, тобто справжній зміст міфу приховується за сюжетною лінією, персонажами і алегоричними образами. Іншими словами, прямий (маніфестантний) зміст міфу приховує таємний (латентний) зміст як домінуючий смисл. Феноменологія міфу проявляється в тому, що поверхневі елементи міфу - міфологічний сюжет, його персонажі та несподівані колізії - ніби «розсіюють» нашу увагу, перш ніж вдається знайти його «серцевину», тобто смисл. Таким чином, для правильного прочитання міфу ми повинні відволіктися від домінуючої частини і звернути увагу на його другорядний план.

Символічна фіксація повідомлень дешифрується методом аналогії,- вважає К.-Г. Юнг, який дозволяє вивести невідоме значення на поверхню смислового сприйняття. В аналітичній психології метод асоціативної аналогії отримав назву ампліфікації (розширення) як метод поступового наближення інтерпретованого символу до його контекстуального смислу. Ампліфікація розгортається у відповідності з міфологічними, релігійними, етичними та іншими мотивами колективної свідомості і відтворює «архетипну» тему. Юнг приходить до вельми сміливого висновку, що репрезентує символ (архетип) як функцію впорядкування реальності; форму перед-існування [11, с. 203]. В даному разі ми можемо фіксувати певні аналогії з ідеями Е. Кассірера, якщо 
розглядати обидва підходи у найбільш загальному вигляді ${ }^{4}$.

Та чи дійсно пов'язані структури реальності, міфу та мислення? Так, К.-Г. Юнг відстоює думку про «транспсихічну реальність», в якій втрачають своє значення причинно-наслідкові зв'язки та матеріальні закони. На його думку міфологічні образи архетипів - універсальних структур свідомості - грають провідну роль в пізнавальній діяльності та відображуються у висновках дослідників. 3 його погляду, платонівські, а потім і декартівські ідеї є вираженням архетипів, тобто $\epsilon$ зовнішніми проекціми внутрішнього порядку і той порядок, що пануе у космосі $\epsilon$ аналогом внутрішього порядку. Суб'єктивні переживання мають витоки у міфо-символічних образах як впорядкованих універсальних структурах.

3 цим можна погоджуватися, як можна і спростовувати, але важко заперечити, що редукція міфу (символу) призводить до втрати універсальної дискурсивної форми, принципу, що зберігає функціональність мови та мислення як способу творення або конституювання себе.

Отже, в ході дослідження ми дійшли таких висновків:

- Міф $є$ архаїчною глибинною структурою свідомості.

- Елементом такої структури є міфема.

- «Логіка» міфу полягає у демонстрації другорядного змістового плану.

- Інформаційний каркас (повідомлення) міфу вибудовується як «прихований» план, що проступає у непрямій позасюжетній лінії.

- Міф демонструє феномен «мовної аберації» та логічної інверсії: відсилає не до реального прототипу, а до умовного репрезентанта і будується за видозміненою логікою або ж «логікою парадоксу».

- Можна припустити «когерентність» образів-символів та символів-абстракцій, якими оперує мова філософії та науки.

- Міф є інваріантом людської психіки, що забезпечує реалізацію «життєвого плану».

\footnotetext{
${ }^{4}$ Зауважимо, що міфологічну модель як спосіб впорядкування реальності використовували Піфагор, Платон, а особливо Геракліт, який виражав свої повідомлення за допомогою неясних метафор, через що отримав прізвисько «Темний». 3 іменем Гермеса та Орфея пов'язують піфагореїзм, з іменем Аполлона - Платона. Вважалося, що Платон був служителем Аполона, Світлого бога, так як і час його народження вказував на його зв'язок з Аполлоном, він народився в сьомий день Таргеліона, коли греки вшановували Аполлона.
} 


\section{1 Бібліографія}

[1] Берн Э. Люди, которые играют в игры. - М.: Изд-во Эксмо, 2002.

[2] Кассирер Э. Эссе о человеке. Введение в философию человеческой культуры // Вестник МУ. - 1993. - № 1.- С. 3-27.

[3] Леви-Строс К. Структурная антропология.-M, 1983.

[4] Лосев А.Ф. Фрагменты из Дополнений к «Диалектике мифа»// Вопросы философии. - 2000. - № 3.- С. 63-70.

[5] Майданов А.С. Миф как источник знания // Вопросы философии. - 2004. - № 9. - С. 91-106.

[6] Фрейд З. Здобування й упокорення вогню // Філософська і соціологічна думка. - 1993. - № 7-8. - С. 195-201.

[7] Фромм Э. Догмат о Христе.-М.: Олимп, ООО «Изд-во АСТЛТД», 1998.

[8] Фуко М. О начале герменевтики себя // Логос. - 2008. - № 2 (65). - C. $96-123$.

[9] Хюбнер К. Истина мифа. - М.: Республика, 1996.

[10] Шопенгауэр А. Об интересном. - М: Олимп, 1997.

[11] Юнг К.-Г. Аналитическая психология. - М.: Мартис, 1995. 